Article

\title{
Tuning the intermediate reaction barriers by a CuPd catalyst to improve the selectivity of $\mathrm{CO}_{2}$ electroreduction to $\mathrm{C} 2$ products
}

\author{
Li Zhu a, Yiyang Lin a, Kang Liu a , Emiliano Cortés ${ }^{b}$, Hongmei Li a , Junhua Huc, Akira Yamaguchi d, \\ Xiaoliang Liu a,\#, Masahiro Miyauchi d,\$, Junwei Fu a, ${ }^{\ngtr}$, Min Liu a,* \\ a Shenzhen Research Institute, School of Physics and Electronics, Central South University, Changsha 410083, Hunan, China \\ b Chair in Hybrid Nanosystems, Nanoinstitute Munich, Faculty of Physics, Ludwig-Maximilians-Universität München, 80539 München, Germany \\ c School of Materials Science and Engineering, Zhengzhou University, Zhengzhou 450052, Henan, China \\ d Department of Materials Science and Engineering, School of Materials and Chemical Technology, Tokyo Institute of Technology, Tokyo 152-8552, Japan
}

\section{A R T I C L E I N F}

\section{Article history:}

Received 18 November 2020

Accepted 9 December 2020

Available online 5 May 2021

\section{Keywords:}

Carbon dioxide reduction

C2 products

Electrocatalyst

Copper-palladium interface

Intermediate reaction barriers

\section{A B S T R A C T}

Electrochemical $\mathrm{CO}_{2}$ reduction is a promising strategy for the utilization of $\mathrm{CO}_{2}$ and intermittent excess electricity. $\mathrm{Cu}$ is the only single metal catalyst that can electrochemically convert $\mathrm{CO}_{2}$ into multicarbon products. However, $\mathrm{Cu}$ exhibits an unfavorable activity and selectivity for the generation of $\mathrm{C} 2$ products because of the insufficient amount of $\mathrm{CO}^{*}$ provided for the $\mathrm{C}-\mathrm{C}$ coupling. Based on the strong $\mathrm{CO}_{2}$ adsorption and ultrafast reaction kinetics of $\mathrm{CO}^{*}$ formation on $\mathrm{Pd}$, an intimate $\mathrm{CuPd}(100)$ interface was designed to lower the intermediate reaction barriers and improve the efficiency of C2 product formation. Density functional theory (DFT) calculations showed that the $\mathrm{CuPd}(100)$ interface enhanced the $\mathrm{CO}_{2}$ adsorption and decreased the $\mathrm{CO}_{2}$ * hydrogenation energy barrier, which was beneficial for the $\mathrm{C}-\mathrm{C}$ coupling. The potential-determining step (PDS) barrier of $\mathrm{CO}_{2}$ to $\mathrm{C} 2$ products on the $\mathrm{CuPd}(100)$ interface was $0.61 \mathrm{eV}$, which was lower than that on $\mathrm{Cu}(100)$ $(0.72 \mathrm{eV})$. Encouraged by the DFT calculation results, the CuPd(100) interface catalyst was prepared by a facile chemical solution method and characterized by transmission electron microscopy. $\mathrm{CO}_{2}$ temperature-programmed desorption and gas sensor experiments further confirmed the enhancement of the $\mathrm{CO}_{2}$ adsorption and $\mathrm{CO}_{2}{ }^{*}$ hydrogenation ability of the $\mathrm{CuPd}(100)$ interface catalyst. Specifically, the obtained CuPd(100) interface catalyst exhibited a C2 Faradaic efficiency of $50.3 \% \pm$ $1.2 \%$ at $-1.4 \mathrm{~V}_{\mathrm{RHE}}$ in $0.1 \mathrm{M} \mathrm{KHCO}_{3}$, which was 2.1 times higher than that of the Cu catalyst $(23.6 \% \pm$ $1.5 \%)$. This study provides the basis for the rational design of $\mathrm{Cu}$-based electrocatalysts for the generation of multicarbon products by fine-tuning the intermediate reaction barriers.

(C) 2021, Dalian Institute of Chemical Physics, Chinese Academy of Sciences.

Published by Elsevier B.V. All rights reserved.

\section{Introduction}

Excessive carbon emissions have caused serious global en- vironmental issues [1-3]. The use of intermittent excess electricity to electrochemically convert $\mathrm{CO}_{2}$ into valuable chemicals is a potential strategy to simultaneously solve the Earth's car-

\footnotetext{
*Corresponding author. Tel: +86-13787082527; E-mail: minliu@csu.edu.cn

* Corresponding author. E-mail: xl_liu@csu.edu.cn

\$Corresponding author. E-mail: mmiyauchi@ceram.titech.ac.jp

${ }^{¥}$ Corresponding author. E-mail: fujunwei@csu.edu.cn

This work was supported by the Natural Science Foundation of China (21872174, 22002189, 51673217, U1932148), the International Science and Technology Cooperation Program (2017YFE0127800, 2018YFE0203402), the Hunan Provincial Science and Technology Program (2017XK2026), the Hunan Provincial Natural Science Foundation (2020JJ2041, 2020JJ5691), the Hunan Provincial Science and Technology Plan Project (2017TP1001), the Shenzhen Science and Technology Innovation Project (JCYJ20180307151313532).

DOI: 10.1016/S1872-2067(20)63754-8 | http://www.sciencedirect.com/science/journal/18722067 | Chin. J. Catal., Vol. 42, No. 9, September 2021
} 
bon recycling and energy crises [4-8]. Among various $\mathrm{CO}_{2}$ reduction products, $\mathrm{C} 2$ products (e.g., $\mathrm{C}_{2} \mathrm{H}_{4}$ and $\mathrm{C}_{2} \mathrm{H}_{5} \mathrm{OH}$ ) have attracted much attention due to their higher energy density compared with $\mathrm{C} 1$ products (e.g., $\mathrm{HCOOH}$ and $\mathrm{CH}_{4}, \mathrm{CH}_{3} \mathrm{OH}$ ) [9-11]. $\mathrm{Cu}$ is a unique single metal catalyst that can promote the electrochemical reduction of $\mathrm{CO}_{2}$ to multicarbon $\left(\mathrm{C}_{2+}\right)$ products [12-14]. However, pure $\mathrm{Cu}$ catalysts lack the desirable activity and selectivity toward $\mathrm{C} 2$ products for practical applications $[15,16]$. The improvement of the efficiency of C2 product generation using $\mathrm{Cu}$ and $\mathrm{Cu}$-based catalysts has aroused great interest [17-20].

There are two limiting factors for achieving the electroreduction of $\mathrm{CO}_{2}$ to $\mathrm{C} 2$ products, namely the amount of $\mathrm{CO}^{*}$ as carbon source ${ }^{*}$ indicates the adsorbate on the surface of a substrate) [21] and the C-C coupling step (two adjacent CO* coupling) [22,23]. For $\mathrm{Cu}$ catalysts, the energy barrier of the $\mathrm{C}-\mathrm{C}$ coupling step is relatively low $[24,25]$. However, the $\mathrm{CO}_{2}$ adsorption and $\mathrm{CO}_{2}$ * hydrogenation ability of $\mathrm{Cu}$ are unfavorable $[26,27]$, resulting in an insufficient amount of adsorbed CO*. Therefore, different approaches have been explored to improve the catalytic activity of $\mathrm{Cu}$ for the generation of $\mathrm{C} 2$ products [28-30]. Among these, the design of $\mathrm{Cu}$-based bimetallic catalysts is one of the most promising strategies [31-33]. In principle, a second metal component can effectively adjust the binding energy between the catalyst and intermediates [34-36], lower the energy barriers of intermediate reactions, and further increase the efficiency of C2 product formation $[37,38]$. Palladium is an efficient catalyst that exhibited strong $\mathrm{CO}_{2}$ adsorption and ultrafast reaction kinetics for $\mathrm{CO}^{*}$ formation. However, $\mathrm{CO}^{*}$ poisoning on the Pd surface makes it unsuitable for generating $\mathrm{C} 2$ products [39]. To take full advantage of both $\mathrm{Cu}$ (C-C coupling) and $\mathrm{Pd}\left(\mathrm{CO}^{*}\right.$ formation), the assembly of a CuPd bimetallic catalyst was envisaged as a potential method for optimizing the efficiency of C2 product formation.

In this study, we developed a CuPd(100) interface catalyst to tune the barriers of intermediate reaction and improve $\mathrm{C} 2$ product selectivity. Density functional theory (DFT) calculations predicted that the $\mathrm{CuPd}(100)$ interface could more strongly adsorb $\mathrm{CO}_{2}$ and dramatically decrease the energy barrier of $\mathrm{CO}_{2}{ }^{*}$ hydrogenation compared with the $\mathrm{Cu}(100)$ facet, leading to sufficient $\mathrm{CO}^{*}$ for the later $\mathrm{C}-\mathrm{C}$ coupling step. The calculated potential-determining step (PDS) of $\mathrm{CO}_{2}$ conversion to $\mathrm{C} 2$ products in the presence of the $\mathrm{CuPd}(100)$ interface was a $\mathrm{C}-\mathrm{C}$ coupling with an energy barrier of $0.61 \mathrm{eV}$, which was much lower than that of $0.72 \mathrm{eV}$ observed for the PDS $\left(\mathrm{CO}_{2}\right.$ * hydrogenation) using $\mathrm{Cu}(100)$, indicating a potentially higher efficiency of $\mathrm{C} 2$ product formation in the case of the CuPd(100) interface catalyst. Experimentally, the CuPd(100) interface catalyst was prepared using an in-situ growth method based on thermal reduction to afford Pd nanoparticles (NPs) as nucleation seeds. The obtained CuPd(100) interface catalyst was characterized using X-ray diffraction (XRD), transmission electron microscopy (TEM), and X-ray photoelectron spectroscopy (XPS) analyses. The enhancement of $\mathrm{CO}_{2}$ adsorption and $\mathrm{CO}_{2}$ * hydrogenation abilities on the $\mathrm{CuPd}(100)$ interface were demonstrated by performing $\mathrm{CO}_{2}$-TPD and gas sensor experiments, respectively. Specifically, the CuPd(100) interface cata- lyst exhibited a C2 Faradaic efficiency (FE) of 50.3\% $\pm 1.2 \%$ at $-1.4 \mathrm{~V}_{\mathrm{RHE}}$ in $0.1 \mathrm{M} \mathrm{KHCO}_{3}$, which was 2.1 times higher than that of the parent $\mathrm{Cu}$ catalyst $(23.6 \% \pm 1.5 \%)$. This study provides a strategy to improve the yield of target $\mathrm{C} 2$ products by regulating the energy barrier of the intermediate reactions as well as a reference for the development of $\mathrm{Cu}$-based catalysts with higher efficiency for the generation of multicarbon products.

\section{Experimental}

\subsection{DFT calculations}

To explore the mechanism of the $\mathrm{CO}_{2}$ conversion to $\mathrm{C} 2$ products, $4 \times 2 \mathrm{Cu}(100), \mathrm{Pd}(100)$, and $\mathrm{CuPd}(100)$ periodic surface slabs with four atomic layers were built, as shown in Fig. $\mathrm{S} 1$. Main consideration is that the $\mathrm{Cu}(100)$ facet favored the formation of $\mathrm{C} 2$ products [40,41]. A vacuum slab of $30 \AA$ was added to avoid the interaction influence of the periodic boundary conditions. Each model contained 128 atoms. Potassium (K) ions not only promote the activation of $\mathrm{CO}_{2}$ [42], but also lower the energy barrier of the C-C coupling [24]. Thus, six K ions were added to the model to simulate the actual $\mathrm{CO}_{2}$ reduction process.

DFT calculations were performed by VASP with the projector augment wave (PAW) method $[43,44]$. The exchange and correlation potentials were present in the generalized gradient approximation in combination with the Perdew-Burke- Ernzerhof correlation (GGA-PBE) [45,46]. A $2 \times 2 \times 1$ gamma grid of k-points was used for the Brillouin zone integration. The cutoff energy as well as convergence criteria for energy and force were set as $450 \mathrm{eV}, 10^{-5} \mathrm{eV} /$ atom, and $0.02 \mathrm{eV} / \AA ̊$, respectively.

The adsorption energy was calculated according to the following Eq. (1) [47,48]:

$$
E_{\text {ads }}=E_{\text {substrate+gas }}-\left(E_{\text {substrate }}+E_{\text {gas }}\right)
$$

where $E_{\text {substrate }}$ and $E_{\text {gas }}$ represent the energy of the isolated substrate and gas molecule, respectively, while $E_{\text {substrate+gas }}$ represents the total energy of the gas molecule adsorbed on the substrate. Herein, the substrates refer to the $\mathrm{Cu}(100), \mathrm{Pd}(100)$, and $\mathrm{CuPd}(100)$ interfaces.

The change in Gibbs free energy $(\Delta G)$ for each reaction step is given as follows $[49,50]$ :

$$
\Delta G=\Delta E+\triangle Z P E-T \Delta S
$$

where $\Delta E$ represents the total energy difference between the product and reactant, while $\triangle Z P E$ and $T \Delta S$ indicate the zero-point energy correction and entropy change at $298.15 \mathrm{~K}$, respectively.

\subsection{Catalyst synthesis}

Preparation of the Cu sample: $3 \mathrm{mmol}$ of copper acetate was thoroughly dissolved in $250 \mathrm{~mL}$ of 2-ethoxyethanol under vigorous stirring and Ar bubbling. After $30 \mathrm{~min}, 20 \mathrm{~mL}$ of aq. $\mathrm{NaBH}_{4}(1.5 \mathrm{M})$ was added dropwise to the above solution. The obtained black precipitate was washed several times with water and ethanol. The collected $\mathrm{Cu}$ sample was dried at $60^{\circ} \mathrm{C}$ for $6 \mathrm{~h}$ in vacuum, and then dispersed in isopropyl alcohol [51]. 
Preparation of the Pd sample: $3 \mathrm{mmol}$ of palladium acetate was first dissolved in $30 \mathrm{~mL}$ of acetone, and then $250 \mathrm{~mL}$ of 2-ethoxyethanol was added. Then, $20 \mathrm{~mL}$ of aq. $\mathrm{NaBH}_{4}(1.5 \mathrm{M})$ was added dropwise to the mixture. The obtained black precipitate was washed with water and ethanol several times, dried at $60{ }^{\circ} \mathrm{C}$ for $6 \mathrm{~h}$ in vacuum, and then dispersed in isopropyl alcohol.

Preparation of the CuPd sample: $1.5 \mathrm{mmol}$ of palladium acetate was dissolved in $10 \mathrm{~mL}$ of acetone. Next, $250 \mathrm{~mL}$ of 2-ethoxyethanol was added, and the mixture was heated at 393 $\mathrm{K}$ for $30 \mathrm{~min}$ under vigorous stirring and Ar bubbling. After cooling to room temperature, $20 \mathrm{~mL}$ of copper acetate aqueous solution $(75 \mathrm{mmol} / \mathrm{L})$ was added dropwise with stirring, followed by $20 \mathrm{~mL}$ of $\mathrm{NaBH}_{4}$ aqueous solution $(1.5 \mathrm{M})$. The obtained black precipitate was thoroughly washed with water and ethanol, dried at $60{ }^{\circ} \mathrm{C}$ for $6 \mathrm{~h}$ in vacuum, and then dispersed in isopropyl alcohol.

\section{Results and discussion}

The adsorption energy of $\mathrm{CO}_{2}$ and $\Delta G$ of $\mathrm{CO}_{2} *$ hydrogenation are shown in Figs. 1(a,b), respectively [19,36,52-54]. The adsorption energy of $\mathrm{CO}_{2}$ in the case of the $\mathrm{CuPd}(100)$ interface $(-0.72 \mathrm{eV})$ was higher than that of $\mathrm{Cu}(100)(-0.45 \mathrm{eV})$ but lower than that of $\mathrm{Pd}(100)(-0.91 \mathrm{eV})$. Fig. S3 shows that the adsorption of $\mathrm{CO}_{2}$ on these models without $\mathrm{K}^{+}$was much weaker than in the presence of $\mathrm{K}^{+}$. It can be inferred that $\mathrm{CO}_{2}$ adsorption was strongly enhanced by the presence of $\mathrm{K}^{+}$[42]. The $\Delta G$ of the $\mathrm{CO}_{2}{ }^{*}$ hydrogenation in the presence of the $\mathrm{CuPd}(100)$ interface greatly decreased to $0.13 \mathrm{eV}$ from $0.72 \mathrm{eV}$ in the case of $\mathrm{Cu}(100)$, while being even lower than that on $\mathrm{Pd}(100)(0.40 \mathrm{eV})$. Considering that the zero-point energy and entropy energy correction were extremely small, the $\Delta G$ of the
$\mathrm{CO}_{2} *$ hydrogenation mainly depended on the difference between $E_{\text {substrate+}}+\mathrm{COOH}^{*}$ and $E_{\text {substrate+CO2* }}$. The more negative the $E_{\text {substrate+}+\mathrm{COOH}^{*}}$ (the stronger the $\mathrm{COOH}^{*}$ adsorption on the substrate) and the more positive the $E_{\text {substrate+Co2* }}$ (the weaker $\mathrm{CO}_{2}$ * adsorption on the substrate), the smaller is the $\Delta G$ of the $\mathrm{CO}_{2}$ * hydrogenation. Therefore, the dramatic decrease in $\Delta G$ of the $\mathrm{CO}_{2}{ }^{*}$ hydrogenation on the $\mathrm{CuPd}(100)$ interface could be attributed to a strong $\mathrm{COOH}^{*}$ adsorption and appropriate $\mathrm{CO}_{2}$ adsorption of the CuPd(100) interface (Figs. S2 and S3).

Fig. S5(a) shows the adsorption energy of $\mathrm{CO}^{*}$ on $\mathrm{Cu}(100)$, $\mathrm{CuPd}(100)$ interface, and $\mathrm{Pd}(100)$ facet with $\mathrm{K}$ ions to be -1.2 , -2 , and $-2.4 \mathrm{eV}$, respectively. Thus, a higher amount of $\mathrm{CO}^{*}$ is formed on the $\mathrm{CuPd}(100)$ interface compared with that on the $\mathrm{Cu}(100)$ facet, leading to an increased chance of the C-C coupling step occurring. In addition, the adsorption energies of $\mathrm{CO}^{*}$ relative to different $\mathrm{CO}^{*}$ coverages on the $\mathrm{Pd}(100)$ facet are shown in Fig. S5(b). These results demonstrated that adsorption of $\mathrm{CO}^{*}$ on $\mathrm{Pd}(100)$ decreased as the $\mathrm{CO}^{*}$ coverage increased, which indicates that $\mathrm{CO}^{*}$ desorption from $\mathrm{Pd}$ is possible at high $\mathrm{CO}^{*}$ coverages [55].

Fig. S6 shows that the energy barriers of the two $\mathrm{CO}^{*}$ couplings in the presence of $\mathrm{Cu}(100)$ and $\mathrm{CuPd}(100)$ were lower than that of the $\mathrm{CO}^{*}$ hydrogenation. Therefore, it can be assumed that the $\mathrm{C}-\mathrm{C}$ coupling step using $\mathrm{Cu}(100)$ and $\mathrm{CuPd}(100)$ involved two $\mathrm{CO}^{*}$ couplings rather than two $\mathrm{COH}^{*} / \mathrm{CHO}^{*}$ coupling. The obtained free energies of the two $\mathrm{CO}^{*}$ coupling on the $\mathrm{Cu}(100), \mathrm{CuPd}(100)$, and $\mathrm{Pd}(100)$ facet were $0.09,0.61$, and $1.44 \mathrm{eV}$, respectively (Fig. 1(b)). The large $\Delta G$ observed for the $\mathrm{Pd}(100)$ facet was consistent with previously reported results, proving that Pd did not exert catalytic activity for $\mathrm{C} 2$ product generation.

As previously reported, the PDS step of the $\mathrm{CO}_{2}$ electroreduction to $\mathrm{C} 2$ products was either the $\mathrm{CO}_{2}$ activation or $\mathrm{C}-\mathrm{C}$
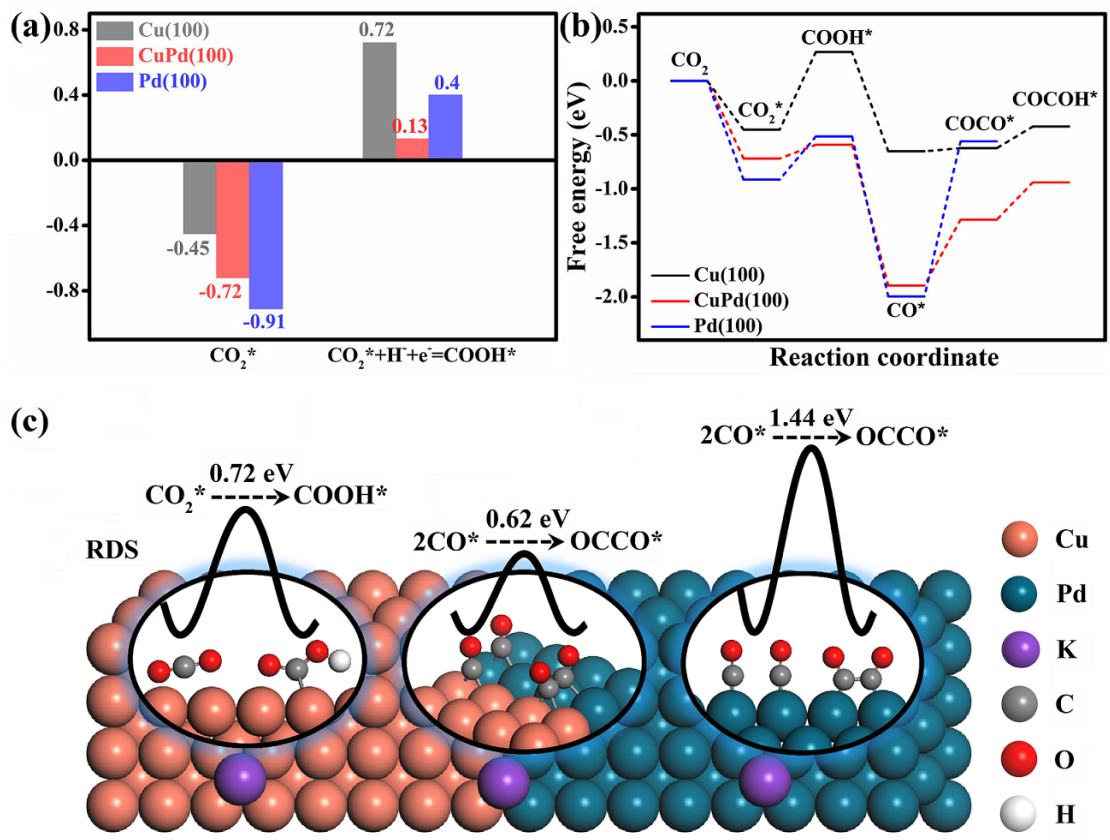

Fig. 1. (a) Adsorption energy of $\mathrm{CO}_{2}$ and $\Delta G$ of $\mathrm{CO}_{2}{ }^{*}$ hydrogenation; (b) Calculated free energy diagrams for the $\mathrm{CO}_{2}$ reduction process; (c) Schematic diagram of the PDS of the $\mathrm{CO}_{2}$ reduction process on $\mathrm{Cu}(100), \mathrm{CuPd}(100)$ interface, and $\mathrm{Pd}(100)$ facet. 
coupling [40]; therefore, it was suggested that the PDS of the $\mathrm{CO}_{2}$ reduction to $\mathrm{C} 2$ products using the $\mathrm{CuPd}(100)$ interface was a C-C coupling with an energy barrier of $0.61 \mathrm{eV}$, which was less than $0.72 \mathrm{eV}$ for the $\mathrm{CO}_{2} *$ hydrogenation on $\mathrm{Cu}(100)$. Therefore, the $\mathrm{CuPd}(100)$ interface was more effective in facilitating the conversion of $\mathrm{CO}_{2}$ to $\mathrm{C} 2$ products compared with the $\mathrm{Cu}(100)$ facet.

Encouraged by these predictions, we prepared the $\mathrm{Cu}, \mathrm{CuPd}$, and Pd samples using a thermal reduction treatment followed by an in situ growth process. As shown in Fig. S4, the XRD patterns indicated that the CuPd sample before electrochemical reduction contained the characteristic peaks of $\mathrm{Cu}$ (PDF No. 03-1015), Pd (PDF No. 05-0681), and $\mathrm{Cu}_{2} \mathrm{O}$ (PDF No. 78-0428). After electrochemical reduction for $30 \mathrm{~min}$, the characteristic $\mathrm{Cu}_{2} \mathrm{O}$ peak disappeared (Fig. 2(a)). These results revealed that the effect of the oxidation state of $\mathrm{Cu}$ on the catalytic activity of these catalysts was negligible, and the CuPd sample consisted of separate $\mathrm{Cu}$ and Pd phases rather than a CuPd alloy $[51,56]$. Fig. 2(b) shows the TEM image of the CuPd sample, which exhibited a typical nanoparticle morphology with a size of approximately $20 \mathrm{~nm}$. The high-resolution TEM (HRTEM) image (Fig. 2(c)) shows lattice distances of 0.182 and $0.194 \mathrm{~nm}$, which corresponded to the $\mathrm{Cu}(100)$ and $\mathrm{Pd}(100)$ facets, respectively [29], while the red line shows a clear CuPd(100) interface. Fig. 2(d) shows the HAADF-STEM and EDS mapping images, demonstrating the separate distribution of the $\mathrm{Cu}$ (green) and Pd (red) phases. The TEM and HRTEM images of the $\mathrm{Cu}$ and $\mathrm{Pd}$ samples are shown in Fig. S5; the lattice distances of 0.181 and $0.195 \mathrm{~nm}$ corresponded to the $\mathrm{Cu}(100)$ facet of the $\mathrm{Cu}$ sample and Pd(100) facet of the Pd sample, respectively.

XPS was further used to study the composition and elemental chemical state of the samples [57-59]. As shown in Figs. $3(\mathrm{a}, \mathrm{b})$, the $\mathrm{Cu} 2 p$ binding energy of the CuPd sample exhibited a $0.2 \mathrm{eV}$ positive shift compared with the $\mathrm{Cu}$ sample, while its $\mathrm{Pd}$ $3 d$ binding energy moved by $0.16 \mathrm{eV}$ toward the low energy region compared with in case of the Pd sample. The slight shifts in the binding energies of $\mathrm{Cu} 2 p$ and $\mathrm{Pd} 3 d$ indicated an electron transfer from $\mathrm{Cu}$ to $\mathrm{Pd}$, revealing an intimate interaction between $\mathrm{Cu}$ and Pd in the CuPd sample [30]. Figs. 3(c,d) show the $\mathrm{Cu} K$ - and $\mathrm{Pd} K$-edge extended X-ray absorption fine structure (EXAFS) spectra of the CuPd sample. Only the $\mathrm{Cu}-\mathrm{Cu}$ and $\mathrm{Pd}-\mathrm{Pd}$ bonds are visible in the spectra. The XPS and EXAFS results together with those of the XRD and TEM analyses clearly demonstrated that the obtained CuPd catalyst consisted of a phase-separated sample with $\mathrm{CuPd}(100)$ interfaces.

To characterize the $\mathrm{CO}_{2}$ adsorption ability of the three catalysts, $\mathrm{CO}_{2}$-TPD measurements and thermogravimetric experiments were carried out (Fig. 4(a) and Fig. S6). The main $\mathrm{CO}_{2}$ desorption peak of the $\mathrm{Cu}$ catalyst was located at $296^{\circ} \mathrm{C}[60]$, while that of the $\mathrm{Pd}$ catalyst was positioned at $608{ }^{\circ} \mathrm{C}$ [61]. In contrast, three main $\mathrm{CO}_{2}$ desorption peaks at 288, 355, and 598 ${ }^{\circ} \mathrm{C}$ were observed for the $\mathrm{CuPd}(100)$ interface catalyst. Unlike the $\mathrm{Cu}$ and $\mathrm{Pd}$ catalysts, the peak located at $355^{\circ} \mathrm{C}$ could be assigned to the $\mathrm{CuPd}(100)$ interface, suggesting a stronger and weaker $\mathrm{CO}_{2}$ adsorption than that on $\mathrm{Cu}$ and $\mathrm{Pd}$, respectively.

To prove the strong $\mathrm{COOH}^{*}$ adsorption ability of the $\mathrm{CuPd}(100)$ interface catalyst, we designed a gas sensor experiment (Fig. S7) [62,63]. Fig. 4(c) shows the current density curves of the $\mathrm{Cu}, \mathrm{CuPd}(100)$ interface, and Pd catalysts at different applied potentials under vacuum and saturated $\mathrm{CO}_{2}+\mathrm{H}_{2} \mathrm{O}$ atmosphere. Fig. 4(d) shows the calculated current density differences $(\Delta j)$ between the vacuum and $\mathrm{CO}_{2}+\mathrm{H}_{2} \mathrm{O}$ atmosphere. The higher the value of $\Delta j$, the stronger is the adsorption of $\mathrm{CO}_{2}$ and $\mathrm{H}_{2} \mathrm{O}$, which is an important indicator of $\mathrm{COOH}^{*}$ adsorption. These results shows that the $\mathrm{CuPd}(100)$ interface catalyst displayed the strongest $\mathrm{COOH}^{*}$ adsorption ability.

Furthermore, CO-TPD was used to investigate the CO adsorption ability of these three catalysts $[64,65]$. As shown in Fig. 4(b), the CuPd(100) interface catalyst exhibited three evident desorption peaks located at 204,271 , and $529^{\circ} \mathrm{C}$. On the other hand, the reference catalysts $\mathrm{Cu}$ and $\mathrm{Pd}$ showed desorption peaks at 211 and $609{ }^{\circ} \mathrm{C}$, respectively [66,67]. In combination with the three $\mathrm{CO}$ desorption curves, the peak at $271{ }^{\circ} \mathrm{C}$ could be ascribed to the contribution of the CuPd(100) inter-
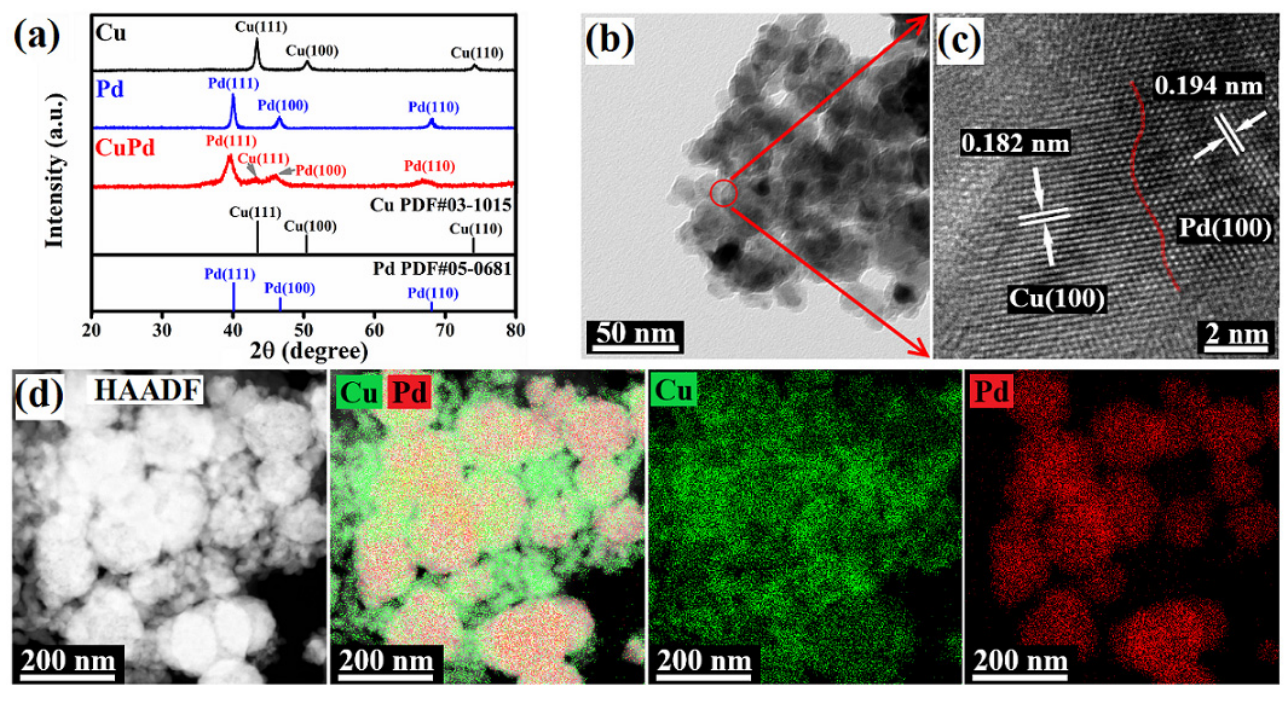

Fig. 2. (a) XRD patterns of the prepared $\mathrm{Cu}, \mathrm{CuPd}$, and $\mathrm{Pd}$ samples after electrochemical reduction for 30 min; (b,c) Low-resolution and high-resolution TEM images of the CuPd sample; (d) HAADF-STEM image combined with the EDS mapping of the CuPd sample. 

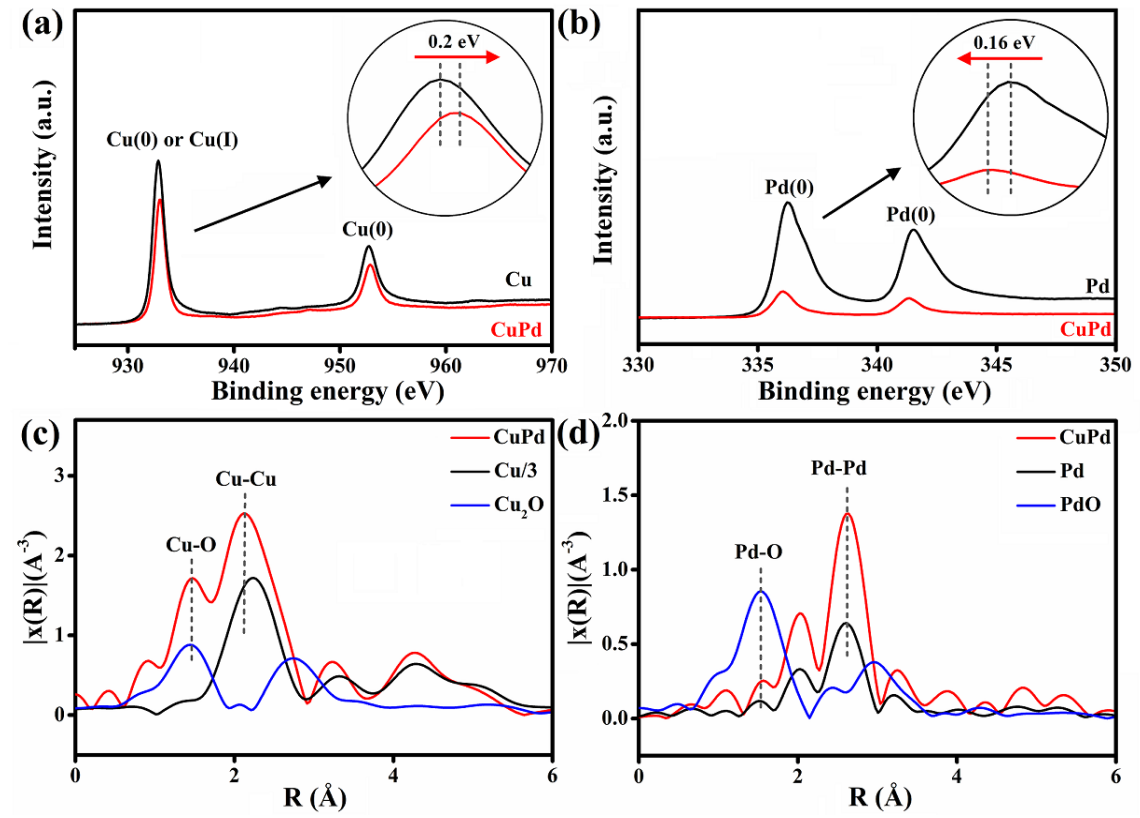

Fig. 3. XPS spectra of $\mathrm{Cu} 2 p(\mathrm{a})$ and Pd $3 d$ (b); EXAFS spectra of $\mathrm{Cu} K$-edge (c) and Pd $K$-edge (d) of the CuPd sample.
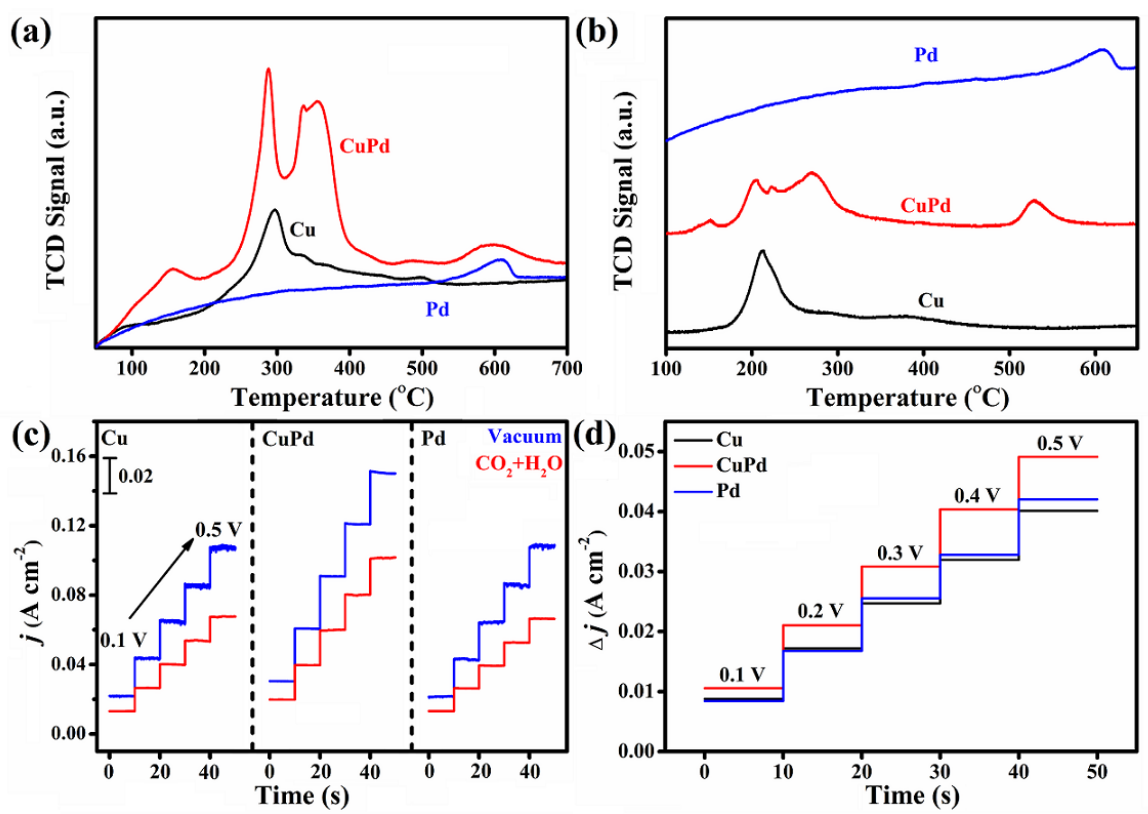

Fig. 4. $\mathrm{CO}_{2}$-TPD (a) and CO-TPD (b) curves of $\mathrm{Cu}, \mathrm{CuPd}(100)$ interface, and Pd catalysts; (c) Gas sensor experiments for $\mathrm{Cu}, \mathrm{CuPd}(100)$ interface, and Pd catalysts at $0.1,0.2,0.3,0.4$, and $0.5 \mathrm{~V}$; (d) Calculated current density differences $\left(\Delta j\right.$ ) between vacuum and $\mathrm{CO}_{2}+\mathrm{H}_{2} \mathrm{O}$ atmosphere.

face. The moderate desorption temperature $\left(271^{\circ} \mathrm{C}\right)$ of the $\mathrm{CuPd}(100)$ interface compared with $\mathrm{Cu}\left(204{ }^{\circ} \mathrm{C}\right)$ and $\mathrm{Pd}(609$ $\left.{ }^{\circ} \mathrm{C}\right)$ suggested a moderate $\mathrm{CO}$ adsorption ability of the CuPd(100) interface.

To assess the catalytic activity of the CuPd(100) interface catalyst, a $\mathrm{CO}_{2}$ electroreduction test was performed. As shown in Fig. 5(a), for the $\mathrm{Cu}$ catalyst, the FE of $\mathrm{C} 2$ products gradually increased from $3.7 \% \pm 0.4 \%$ to $23.6 \% \pm 1.5 \%$ at a cathode potential ranging from -0.8 to $-1.4 \mathrm{~V}_{\mathrm{RHE}}$, while the $\mathrm{FE}$ of $\mathrm{C} 1$ products accordingly decreased from $54.7 \% \pm 1.3 \%$ to $30.6 \% \pm$ $1.4 \%$ within the same potential range. For the CuPd(100) interface catalyst, the $\mathrm{FE}$ of $\mathrm{C} 2$ products increased from $7 \% \pm$ $0.6 \%$ to $50.3 \% \pm 1.2 \%$ at the corresponding potentials, which was 2.1 times higher than that of the $\mathrm{Cu}$ catalyst $(23.6 \% \pm$ $1.5 \%)$. For the Pd catalyst, only $\mathrm{C} 1$ products and $\mathrm{H}_{2}$ were detected, and the FE of $\mathrm{H}_{2}$ gradually increased as the cathode potential increased negatively. More detailed data on the FE of the products of these three catalysts are shown in Fig. S8.

To analyze the selectivity of $\mathrm{C} 2$ products, the $\mathrm{FE}$ ratios of $\mathrm{C} 2$ to $\mathrm{C} 1$ products $\left(\mathrm{FE}_{\mathrm{C} 2} / \mathrm{FE}_{\mathrm{C} 1}\right)$ at different applied potentials were determined, as shown in Fig. 5(b). At all applied potentials, the $\mathrm{FE}_{\mathrm{C} 2} / \mathrm{FE}_{\mathrm{C} 1}$ of the $\mathrm{CuPd}(100)$ interface catalyst was larger than that of the $\mathrm{Cu}$ catalyst. In particular, at $-1.4 \mathrm{~V}_{\mathrm{RHE}}$ the $\mathrm{FE}_{\mathrm{C} 2} / \mathrm{FE}_{\mathrm{C} 1}$ of the $\mathrm{CuPd}(100)$ interface catalyst reached 2.4, while that of the $\mathrm{Cu}$ catalyst was 0.77 . This result proved a higher selectivity toward C2 products of the $\mathrm{CuPd}(100)$ interface catalyst than 
that of the $\mathrm{Cu}$ catalyst. As previously mentioned, $\mathrm{C} 2$ products were not detected in the presence of the Pd catalyst.

Fig. 5(c) shows the current densities at different cathode potentials. The current density of the CuPd(100) interface catalyst was significantly greater than that of the $\mathrm{Cu}$ and $\mathrm{Pd}$ catalysts at each potential, indicating faster reaction kinetics for the CuPd(100) interface catalyst. This performance was also confirmed by linear sweep voltammetry (LSV) curves (Fig. S9). Moreover, the $\mathrm{CuPd}(100)$ interface catalyst displayed the lowest Tafel slope (374 $\mathrm{mV} \mathrm{dec}^{-1}$ ) compared with the $\mathrm{Cu}(384 \mathrm{mV}$ $\mathrm{dec}^{-1}$ ) and Pd (467 mV dec ${ }^{-1}$ ) catalyst (Fig. 5(d)), demonstrating rapid $\mathrm{C} 2$ product generation kinetics in the presence of the CuPd(100) interface.

Furthermore, electrochemically active surface area (ECSA) tests showed that the $\mathrm{CuPd}(100)$ interface catalyst possessed the highest ECSA $\left(7.04 \times 10^{-3} \mathrm{mF} \mathrm{cm}^{-2}\right)$, followed by the $\mathrm{Cu}$ $\left(1.84 \times 10^{-3} \mathrm{mF} \mathrm{cm}^{-2}\right)$ and Pd catalyst $\left(0.99 \times 10^{-3} \mathrm{mF} \mathrm{cm}^{-2}\right)$ (Fig. S10). The electrochemical impedance spectra (EIS) show that the $\mathrm{CuPd}(100)$ interface catalyst possessed the best electrical conductivity among the three catalysts (Fig. S11). These results proved that the CuPd(100) interface catalyst displayed a greater activity and selectivity toward C2 products than both $\mathrm{Cu}$ and Pd catalysts.

\section{Conclusions}

In summary, DFT calculations predicted that a $\mathrm{CuPd}(100)$ interface catalyst could possess a higher efficiency for the generation of $\mathrm{C} 2$ products during a $\mathrm{CO}_{2}$ electroreduction reaction compared with that of $\mathrm{Cu}$ or Pd monometallic catalysts. These calculations showed that the $\mathrm{CuPd}(100)$ interface catalyst could provide sufficient $\mathrm{CO}^{*}$ for the $\mathrm{C}-\mathrm{C}$ coupling by enhancing the $\mathrm{CO}_{2}$ adsorption and decreasing the energy barrier of the $\mathrm{CO}_{2}$ * hydrogenation step. The PDS energy barrier of $\mathrm{CO}_{2}$ conversion to $\mathrm{C} 2$ products on the $\mathrm{CuPd}(100)$ interface catalyst $(0.61 \mathrm{eV})$ was smaller than that of $\mathrm{Cu}(100)(0.72 \mathrm{eV})$. Guided by these theoretical predictions, the $\mathrm{CuPd}(100)$ interface catalyst was synthesized using a thermal reduction treatment followed by an in-situ growth process. The $\mathrm{CuPd}(100)$ interface was clearly visible in the corresponding HRTEM image. By combining the $\mathrm{CO}_{2}$-TPD results and gas sensor measurements, the enhanced adsorption of $\mathrm{CO}_{2}$ along with the decrease in the energy barrier of the $\mathrm{CO}_{2}{ }^{*}$ hydrogenation on the $\mathrm{CuPd}(100)$ interface were further verified. Specifically, the $\mathrm{CuPd}(100)$ interface catalyst exhibited a C2 $\mathrm{FE}$ of $50.3 \% \pm 1.2 \%$ at $-1.4 \mathrm{~V}$ RHE in $0.1 \mathrm{M} \mathrm{KHCO}_{3}$, which was 2.1 times higher than that of the $\mathrm{Cu}$ catalyst $(23.6 \%$ $\pm 1.5 \%$ ). The consistency between the theoretical and experimental results provided new insights into the design of superior $\mathrm{Cu}$-based electrocatalysts for the conversion of $\mathrm{CO}_{2}$ to desired multicarbon products.

\section{Conflicts of interest}

There are no conflicts to declare.

\section{Author contributions}

Min Liu, Junwei Fu, Masahiro Miyauchi and Xiaoliang Liu supervised the project. Min Liu and Akira Yamaguchi designed the experiments and analysed the results. Li Zhu synthesized the samples, performed the electrochemical experiments, and analysed the results. Li Zhu and Kang Liu carried out the DFT calculation and wrote the corresponding section. Yiyang Lin, Ying-Rui Lu and Ting-Shan Chan conducted the EXAFS measurements, and Emiliano Cortés analysed the results. Junhua $\mathrm{Hu}$ and Hongmei Li carried out the electron microscope measurements. All authors read and commented on the manuscript.

\section{Acknowledgments}

The authors gratefully thank the Natural Science Foundation of China (21872174, 22002189, 51673217, U1932148), the
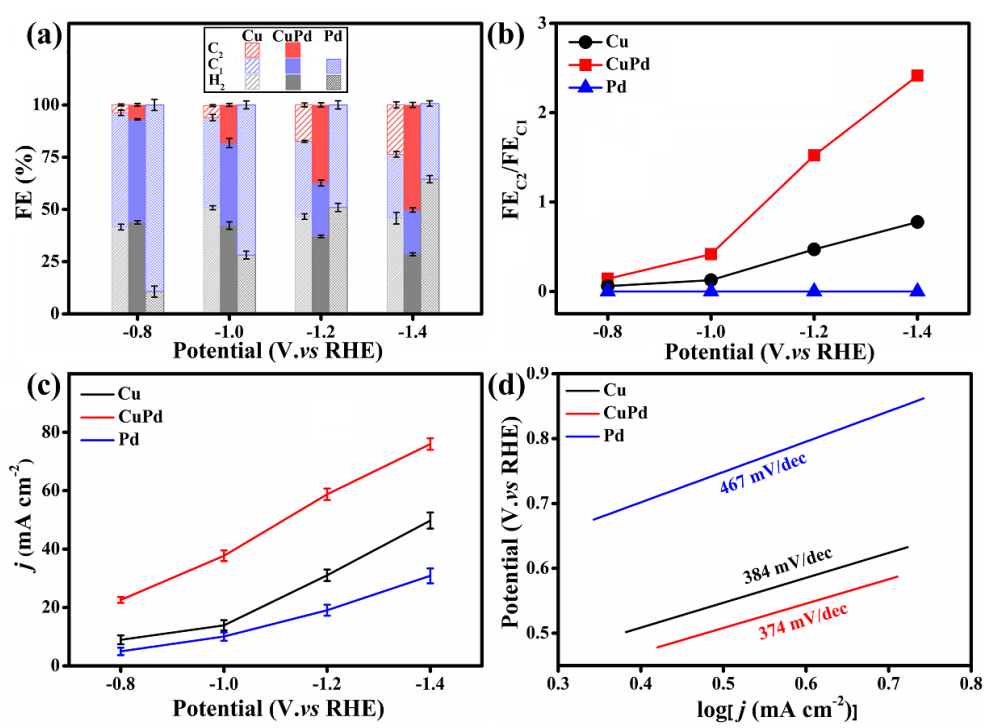

Fig. 5. (a) FE of different products for $\mathrm{Cu}, \mathrm{CuPd}(100)$ interface, and Pd catalysts at different applied potentials; (b) FE ratios of $\mathrm{C} 2$ to $\mathrm{C} 1$ products ( $\mathrm{FE}_{\mathrm{C} 2} / \mathrm{FE}_{\mathrm{c} 1}$ ) at different applied potentials; (c) Current density curves and (d) Tafel slopes for $\mathrm{Cu}$, $\mathrm{CuPd}(100)$ interface, and Pd catalysts. 
International Science and Technology Cooperation Program (2017YFE0127800, 2018YFE0203402), the Hunan Provincial Science and Technology Program (2017XK2026), the Hunan Provincial Natural Science Foundation (2020JJ2041, 2020JJ5691), the Hunan Provincial Science and Technology Plan Project (2017TP1001), the Shenzhen Science and Technology Innovation Project (JCYJ20180307151313532), Ministry of Science and Technology, Taiwan, China (MOST108-2113M-213-006). Emiliano Cortés acknowledges funding and support from the Deutsche Forschungsgemeinschaft (DFG, German Research Foundation) under Germany's Excellence Strategy (EXC 2089/1-390776260), the Bavarian Solar Energies Go Hybrid (SolTech) program and the Center for NanoScience (CeNS), the European Commission for the ERC Starting Grant CATALIGHT (802989).

\section{Electronic supporting information}

Supporting information is available in the online version of this article.

\section{References}

[1] X. Lim, Nature, 2015, 526, 628-630.

[2] O. S. Bushuyev, P. De Luna, C. T. Dinh, L. Tao, G. Saur, J. van de Lagemaat, S. O. Kelley, E. H. Sargent, Joule, 2018, 2, 825-832.

[3] X. Wang, Y. Wang, X. Sang, W. Zheng, S. Zhang, L. Shuai, B. Yang, Z. Li, J. Chen, L. Lei, N. M. Adli, M. K. H. Leung, M. Qiu, G. Wu, Y. Hou, Angew. Chem. Int. Ed., 2020, 10.1002/anie.202013427.

[4] J. Fu, S. Wang, Z. Wang, K. Liu, H. Li, H. Liu, J. Hu, X. Xu, H. Li, M. Liu, Front. Phys., 2020, 15, 33201.

[5] G. Yang, Z. Yu, J. Zhang, Z. Liang, Chin. J. Catal., 2018, 39, 914-919.

[6] J. Hao, W. Shi, Chin. J. Catal., 2018, 39, 1157-1166.

[7] C. Yan, L. Lin, G. Wang, X. Bao, Chin. J. Catal., 2019, 40, 23-37.
[8] S. Feng, W. Zheng, J. Zhu, Z. Li, B. Yang, Z. Wen, J. Lu, L. Lei, S. Wang, Y. Hou, Appl. Catal. B, 2020, 270, 118908.

[9] J. Fu, K. Jiang, X. Qiu, J. Yu, M. Liu, Mater. Today, 2020, 32, 222-243.

[10] J. Shao, Y. Wang, D. Gao, K. Ye, Q. Wang, G. Wang, Chin. J. Catal., 2020, 41, 1393-1400.

[11] T. Wang, X. Sang, W. Zheng, B. Yang, S. Yao, C. Lei, Z. Li, Q. He, J. Lu, L. Lei, L. Dai, Y. Hou, Adv. Mater., 2020, 32, 2002430.

[12] Y. Chen, K. Chen, J. Fu, A. Yamaguchi, H. Li, H. Pan, J. Hu, M. Miyauchi, M. Liu, Nano Mater. Sci., 2020, 2, 235-247.

[13] H. Zhou, K. Liu, H. Li, M. Cao, J. Fu, X. Gao, J. Hu, W. Li, H. Pan, J. Zhan, Q. Li, X. Qiu, M. Liu, J. Colloid Interface Sci., 2019, 550, 17-47.

[14] Y. Zhou, F. Che, M. Liu, C. Zou, Z. Liang, P. De Luna, H. Yuan, J. Li, Z. Wang, H. Xie, H. Li, P. Chen, E. Bladt, R. Quintero-Bermudez, T. K. Sham, S. Bals, J. Hofkens, D. Sinton, G. Chen, E. H. Sargent, Nat. Chem., 2018, 10, 974-980.

[15] S. Jia, Q. Zhu, H. Wu, M. Chu, S. Han, R. Feng, J. Tu, J. Zhai, B. Han, Chin. J. Catal., 2020, 41, 1091-1098.

[16] W. Xiong, J. Yang, L. Shuai, Y. Hou, M. Qiu, X. Li, M. K. H. Leung, ChemElectroChem, 2019, 6, 5951-5957.

[17] P. An, L. Wei, H. Li, B. Yang, K. Liu, J. Fu, H. Li, H. Liu, J. Hu, Y. R. Lu, H. Pan, T.-S. Chan, N. Zhang, M. Liu, J. Mater. Chem. A, 2020, 8, 15936-15941.

[18] J. Wang, Z. Li, C. Dong, Y. Feng, J. Yang, H. Liu, X. Du, ACS Appl. Mater. Interfaces, 2019, 11, 2763-2767.

[19] M. Xing, L. Guo, Z. Hao, Dalton Trans., 2019, 48, 1504-1515.

[20] H. Xiao, W. A. Goddard III, T. Cheng, Y. Liu, Proc. Natl. Acad. Sci. USA, 2017, 114, 6685-6688.

[21] L. Ou, Y. Chen, J. Jin, Chem. Phys. Lett., 2018, 710, 175-179.

[22] G. Mangione, J. Huang, R. Buonsanti, C. Corminboeuf, J. Phys. Chem. Lett., 2019, 10, 4259-4265.

[23] J. H. Montoya, C. Shi, K. Chan, J. K. Norskov, J. Phys. Chem. Lett., 2015, 6, 2032-2037.

[24] E. Perez-Gallent, G. Marcandalli, M. C. Figueiredo, F. Calle-Vallejo, M. T. M. Koper, J. Am. Chem. Soc., 2017, 139, 16412-16419.

[25] T. K. Todorova, M. W. Schreiber, M. Fontecave, ACS Catal., 2019 , $10,1754-1768$.

\section{Graphical Abstract}

Chin. J. Catal., 2021, 42: 1500-1508 doi: 10.1016/S1872-2067(20)63754-8

Tuning the intermediate reaction barriers by a CuPd catalyst to improve the selectivity of $\mathrm{CO}_{2}$ electroreduction to $\mathrm{C} 2$ products

Li Zhu, Yiyang Lin, Kang Liu, Emiliano Cortés, Hongmei Li, Junhua Hu, Akira Yamaguchi, Xiaoliang Liu*, Masahiro Miyauchi*,

Junwei Fu*, Min Liu*

Central South University, China; Ludwig-Maximilians-Universität München, Germany; Zhengzhou University, China;

Tokyo Institute of Technology, Japan

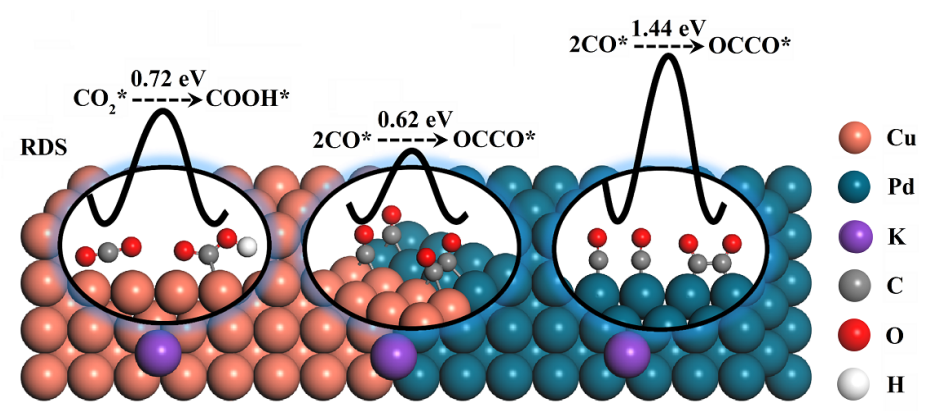

A CuPd(100) catalyst was designed and fabricated to improve the selectivity of the electroreduction of $\mathrm{CO}_{2}$ to $\mathrm{C} 2$ products by tuning the $\mathrm{CO}_{2}$ adsorption ability and intermediate reaction barriers. 
[26] T. Cheng, H. Xiao, W. A. Goddard III, J. Am. Chem. Soc., 2016, 138, 13802-13805.

[27] L. Ou, RSC Adv., 2015, 5, 57361-57371.

[28] S. Bai, Q. Shao, P. Wang, Q. Dai, X. Wang, X. Huang, J. Am. Chem. Soc., 2017, 139, 6827-6830.

[29] J. Gao, H. Zhang, X. Guo, J. Luo, S. M. Zakeeruddin, D. Ren, M. Gratzel, J. Am. Chem. Soc., 2019, 141, 18704-18714.

[30] J. Huang, M. Mensi, E. Oveisi, V. Mantella, R. Buonsanti, J. Am. Chem. Soc., 2019, 141, 2490-2499.

[31] L. Lu, X. Sun, J. Ma, D. Yang, H. Wu, B. Zhang, J. Zhang, B. Han, Angew. Chem. Int. Ed., 2018, 57, 14149-14153.

[32] Z. Weng, X. Zhang, Y. Wu, S. Huo, J. Jiang, W. Liu, G. He, Y. Liang, H. Wang, Angew. Chem. Int. Ed., 2017, 56, 13135-13139.

[33] W. Zhu, L. Zhang, P. Yang, X. Chang, H. Dong, A. Li, C. Hu, Z. Huang, Z. J. Zhao, J. Gong. Small, 2018, 14, 1703314.

[34] D. Chen, Q. Yao, P. Cui, H. Liu, J. Xie, J. Yang, ACS Appl. Energy Mater., 2018, 1, 883-890.

[35] L. Liu, F. Fan, Z. Jiang, X. Gao, J. Wei, T. Fang, J. Phys. Chem. C, 2017, 121, 26287-26299.

[36] X. Nie, X. Jiang, H. Wang, W. Luo, M. J. Janik, Y. Chen, X. Guo, C. Song, ACS Catal., 2018, 8, 4873-4892.

[37] C. S. Chen, J. H. Wan, B. S. Yeo, J. Phys. Chem. C, 2015, 119, 26875-26882.

[38] S. Lee, G. Park, J. Lee, ACS Catal., 2017, 7, 8594-8604.

[39] D. Gao, H. Zhou, F. Cai, J. Wang, G. Wang, X. Bao, ACS Catal., 2018, 8, 1510-1519.

[40] W. Luo, X. Nie, M. J. Janik, A. Asthagiri, ACS Catal., 2015, 6, 219-229.

[41] E. Perez-Gallent, M. C. Figueiredo, F. Calle-Vallejo, M. T. M. Koper, Angew. Chem. Int. Ed., 2017, 56, 3621-3624.

[42] M. Liu, Y. Pang, B. Zhang, P. De Luna, O. Voznyy, J. Xu, X. Zheng, C. T. Dinh, F. Fan, C. Cao, F. P. de Arquer, T. S. Safaei, A. Mepham, A. Klinkova, E. Kumacheva, T. Filleter, D. Sinton, S. O. Kelley, E. H. Sargent, Nature, 2016, 537, 382-386.

[43] G. Kresse, J. Furthmüller, Phys. Rev. B, 1996, 54, 11169-11186.

[44] G. Kresse, D. Joubert, Phys. Rev. B, 1999, 59, 1758-1775.

[45] J. P. Perdew, K. Burke, M. Ernzerhof, Phys. Rev. Lett., 1996, 77, 3865-3868.

[46] J. P. Perdew, Y. Wang, Phys. Rev. B, 1992, 45, 13244-13249.

[47] H. J. W. Li, H. Zhou, K. Chen, K. Liu, S. Li, K. Jiang, W. Zhang, Y. Xie, Z. Cao, H. Li, H. Liu, X. Xu, H. Pan, J. Hu, D. Tang, X. Qiu, J. Fu, M. Liu, Solar RRL, 2020, 4, 1900416.

[48] Y. Huo, J. Zhang, K. Dai, Q. Li, J. Lv, G. Zhu, C. Liang, Appl. Catal. B, 2019, 241, 528-538.
[49] K. Liu, J. Fu, L. Zhu, X. Zhang, H. Li, H. Liu, J. Hu, M. Liu, Nanoscale, 2020, 12, 4903-4908.

[50] M. Liu, M. Liu, X. Wang, S. M. Kozlov, Z. Cao, P. De Luna, H. Li, X. Qiu, K. Liu, J. Hu, C. Jia, P. Wang, H. Zhou, J. He, M. Zhong, X. Lan, Y. Zhou, Z. Wang, J. Li, A. Seifitokaldani, C. T. Dinh, H. Liang, C. Zou, D. Zhang, Y. Yang, T. S. Chan, Y. Han, L. Cavallo, T. K. Sham, B. J. Hwang, E. H. Sargent, Joule, 2019, 3, 1703-1718.

[51] S. Ma, M. Sadakiyo, M. Heima, R. Luo, R. T. Haasch, J. I. Gold, M. Yamauchi, P. J. A. Kenis, J. Am. Chem. Soc., 2017, 139, 47-50.

[52] W. Ju, A. Bagger, X. Wang, Y. Tsai, F. Luo, T. Möller, H. Wang, J. Rossmeisl, A. S. Varela, P. Strasser, ACS Energy Lett., 2019, 4, 1663-1671.

[53] Y. Jiao, Y. Zheng, P. Chen, M. Jaroniec, S. Z. Qiao, J. Am. Chem. Soc., 2017, 139, 18093-18100.

[54] A. A. Peterson, J. K. Nørskov, J. Phys. Chem. Lett., 2012, 3, 251-258.

[55] H. Liu, J. Liu, B. Yang, Phys. Chem. Chem. Phys., 2020, 22, 9600-9606.

[56] X. Liu, Q. Han, Y. Liu, C. Xie, C. Yang, D. Niu, Y. Li, H. Wang, L. Xia, Y. Yuan, Y. Gao, Appl. Phys. Lett., 2020, 116, 253303.

[57] K. Chen, W. Fan, C. Huang, X. Qiu, J. Phys. Chem. Solids, 2017, 110, 9-14.

[58] K. Chen, H. Li, Y. Xu, K. Liu, H. Li, X. Xu, X. Qiu, M. Liu, Nanoscale, 2019, 11, 5967-5973.

[59] P. Liu, X. Liu, L. Lyu, H. Xie, H. Zhang, D. Niu, H. Huang, C. Bi, Z. Xiao, J. Huang, Y. Gao, Appl. Phys. Lett., 2015, 106, 193903.

[60] L. Frusteri, C. Cannilla, S. Todaro, F. Frusteri, G. Bonura, Catalysts, 2019, 9, 1058.

[61] X. Zhang, X. Chen, Y. Liu, M. Guo, Water Air Soil Pollut., 2020, 231, 277.

[62] S. Cao, Y. Chen, H. Wang, J. Chen, X. Shi, H. Li, P. Cheng, X. Liu, M. Liu, L. Piao, Joule, 2018, 2, 549-557.

[63] K. Chen, K. Liu, P. An, H. Li, Y. Lin, J. Hu, C. Jia, J. Fu, H. Li, H. Liu, Z. Lin, W. Li, J. Li, Y. R. Lu, T. S. Chan, N. Zhang, M. Liu, Nat. Commun., 2020, 11, 4173.

[64] J. Fu, K. Liu, K. Jiang, H. Li, P. An, W. Li, N. Zhang, H. Li, X. Xu, H. Zhou, D. Tang, X. Wang, X. Qiu, M. Liu, Adv. Sci., 2019, 6, 1900796.

[65] K. Jiang, L. Zhu, Z. Wang, K. Liu, H. Li, J. Hu, H. Pan, J. Fu, N. Zhang, X. Qiu, M. Liu, Appl. Surf. Sci., 2020, 508, 145173.

[66] J. Butorac, E. L. Wilson, H. H. Fielding, W. A. Brown, R. S. Minns, RSC Adv., 2016, 6, 66346-66359.

[67] A. Kokalj, T. Makino, M. Okada, J. Phys.: Condens. Matter, 2017, 29, 194001.

\section{$\mathrm{CuPd}$ 催化剂调节中间反应能垒提高电催化 $\mathrm{CO}_{2}$ 生成二碳产物的选择性}

朱 莉 ${ }^{\mathrm{a}}$, 林翌阳 ${ }^{\mathrm{a}}$, 刘 康 ${ }^{\mathrm{a}}$, Emiliano Cortés ${ }^{\mathrm{b}}$, 李红梅, 胡俊华 ${ }^{\mathrm{c}}$, Akira Yamaguchi ${ }^{\mathrm{d}}$, 刘小良, ${ }^{\mathrm{a}, \mathrm{A}}$, Masahiro Miyauchi ${ }^{\mathrm{d}, \mathrm{S}}$, 傅俊伟 ${ }^{\mathrm{a}, \mathrm{Y}}$, 刘 敏 $\mathrm{\alpha}^{\mathrm{a}}{ }^{*}$

a中南大学物理与电子学院, 湖南长沙 410083 , 中国

'慕尼黑大学物理学院, 慕尼黑, 德国

c 郑州大学材料科学与工程学院, 河南郑州 450052 , 中国

$\mathrm{d}$ 东京工业大学材料与化工技术学院, 材料与科学工程系, 东京, 日本

摘要: 过度的碳排放已造成了严重的全球环境问题, 电催化 $\mathrm{CO}_{2}$ 还原是一种利用间歇性过剩电能将 $\mathrm{CO}_{2}$ 转化为有价值的化 学物质的有效策略. 在多种 $\mathrm{CO}_{2}$ 还原产物中, 二碳( $\mathrm{C} 2$ )产物(如乙烯、乙醇)因其比一碳产物(如甲酸、甲烷、甲醇)具有更高 的能量密度而备受关注. $\mathrm{Cu}$ 是唯一能用电化学方法将 $\mathrm{CO}_{2}$ 转化为多碳产物的单金属催化剂. 如何提高 $\mathrm{Cu}$ 基催化剂上 $\mathrm{CO}_{2}$ 还原为 $\mathrm{C} 2$ 产物的效率已引起了极大关注. 电催化还原 $\mathrm{CO}_{2}$ 生成 $\mathrm{C} 2$ 产物有两个重要步骤: 一是参与碳碳偶联反应的 $\mathrm{CO} *$ 中 
间体的量(*代表中间体吸附在基底表面), 二是碳碳偶联步骤的能垒. 对于 $\mathrm{Cu}$ 单金属催化剂, 虽然其表面碳碳偶联步骤的能 垒相对较低, 但是 $\mathrm{Cu}$ 对 $\mathrm{CO}_{2}$ 的吸附能力和 $\mathrm{CO}_{2}$ * 加氢能力并不高, 导致在 $\mathrm{Cu}$ 表面不能生成足量的 $\mathrm{CO}$ *中间体参与碳碳偶联反 应, 因而对 $\mathrm{C} 2$ 产物的选择性和活性并不理想. 与 $\mathrm{Cu}$ 单金属催化剂相反, 在 $\mathrm{Pd}$ 单金属催化剂表面, $\mathrm{CO}$ *中间体的形成具有超 快的反应动力学, 但是 $\mathrm{CO}$ *易在 $\mathrm{Pd}$ 表面中毒且后续碳碳偶联步骤的能垒极高, 使其表面不能生成 $\mathrm{C} 2$ 产物. 为了充分发挥 $\mathrm{Cu}$ (碳碳偶联步骤能垒较低)和 $\mathrm{Pd}(\mathrm{CO}$ *形成具有超快反应动力学)的双重优势, 本文构建了一种紧密的 $\mathrm{CuPd}(100)$ 界面, 以调 节中间反应能垒, 从而提高 $\mathrm{C} 2$ 产率.

密度泛函理论(DFT)计算表明, $\mathrm{CuPd}(100)$ 界面增强了 $\mathrm{CO}_{2}$ 的吸附, 且降低了 $\mathrm{CO}_{2}$ * 加氢步骤的能垒, 从而能够催化生成 更多的 $\mathrm{CO}$ *中间体参与碳碳偶联反应. 且 $\mathrm{CuPd}(100)$ 界面上 $\mathrm{CO}_{2}$ 还原为 $\mathrm{C} 2$ 产物的电位决定步骤能垒为 $0.61 \mathrm{eV}$, 低于 $\mathrm{Cu}(100)$ 表面的 $(0.72 \mathrm{eV})$.

本文采用了一种简便的湿化学法制备了 $\mathrm{CuPd}(100)$ 界面催化剂. X射线衍射和X射线光电子能谱测试以及扩展X射线 吸收精细结构光谱结果表明, 合成的是相分离的 CuPd双金属催化剂, 而非CuPd合金催化剂. 同时高分辨透射电镜可以观察 到清晰的 CuPd(100)界面. 由此可见, 本文成功合成了 $\mathrm{CuPd}(100)$ 界面催化剂. 程序升温脱附实验结果表明, $\mathrm{CuPd}(100)$ 界面 对 $\mathrm{CO}_{2}$ 和 $\mathrm{CO}$ *的吸附比 $\mathrm{Cu}$ 强, 结果与理论预测一致. 气体传感实验结果表明, $\mathrm{CuPd}(100)$ 界面 $\mathrm{CO}_{2}{ }^{*}$ 加氢能力比 $\mathrm{Cu}$ 强. 为评估 $\mathrm{CuPd}(100)$ 界面催化剂的催化活性, 进行了 $\mathrm{CO}_{2}$ 电化学还原实验. 结果表明, 在 $0.1 \mathrm{~mol} / \mathrm{L}$ 的 $\mathrm{KHCO}_{3}$ 电解液中, $\mathrm{CuPd}(100)$ 界面 催化剂在 $-1.4 \mathrm{~V}_{\mathrm{RHE}}$ 下, $\mathrm{C} 2$ 产物的法拉第效率为 $50.3 \% \pm 1.2 \%$, 是同电位下Cu催化剂的 $(23.6 \% \pm 1.5 \%)$ 的 2.1 倍, $\mathrm{C} 2$ 产物的选 择性是 $\mathrm{Cu}$ 催化剂的 2.4 倍, 且具有更高的电流密度和更大的电化学活性面积. 本文通过调控中间反应能垒以合理设计铜基 $\mathrm{CO}_{2}$ 还原电催化剂提供了参考.

关键词: 二氧化碳电催化还原; 二碳产物; 铜钯界面催化剂; 中间反应能垒

收稿日期: 2020-11-18. 接受日期: 2020-12-09. 上网时间: 2021-05-05.

*通讯联系人. 电话: 13787082527 ; 电子信箱: minliu@csu.edu.cn

\#通讯联系人. 电子信箱: xl_liu@csu.edu.cn

通讯联系人. 电子信箱: mmiyauchi@ceram.titech.ac.jp

通讯联系人. 电子信箱: fujunwei@csu.edu.cn

基金来源：国家自然科学基金(21872174, 22002189, 51673217, U1932148); 国家科技部重点研发国际间合作项目 (2017YFE0127800, 2018YFE 0203402); 湖南省科技计划项目(2017XK2026); 湖南省自然科学基金(2020JJ2041, 2020JJ5691), 湖 南省科技计划项目(2017TP1001); 深圳科技创新项目(JCYJ20180307151313532).

本文的电子版全文由Elsevier出版社在ScienceDirect上出版(http://www.sciencedirect.com/journal/chinese-journal-of-catalysis. 